A N N A L E S

UNIVERSITATIS MARIAE CURIE-SKŁODOWSKA LUBLIN - POLONIA

VOL. LXXI, z. 1

SECTIO B

2016

Wydział Geografii i Studiów Regionalnych, Uniwersytet Warszawski

00-927 Warszawa, ul. Krakowskie Przedmieście 26/28

krzysztofzabecki@student.uw.edu.pl

\title{
KRZYSZTOF ZĄBECKI
}

\section{Miejsce geografii w badaniach nad językami. Między geografią języków a geografią lingwistyczną}

The place of geography in studying languages. Between geography

of languages and linguistic geography

Słowa kluczowe: geografia języków, geografia językowa, geografia lingwistyczna, geolingwistyka, językoznawstwo

Keywords: geography of languages, language geography, linguistic geography, geolinguistics, linguistics

\section{WPROWADZENIE}

Język jako sposób komunikowania się jest jednym z kluczowych elementów wyróżniających gatunek ludzki ${ }^{1}$. Stanowi zarazem czynnik, dzięki któremu człowiek może formułować abstrakcyjne idee, opisywać rzeczywistość, porządkować myśli i dzielić się nimi z innymi (Warf 2006). Umożliwiając abstrakcyjne myślenie, język pozwala jednocześnie tworzyć wiedzę, przekazywać ją oraz korzystać z wiedzy wytworzonej przez innych, stanowi tym samym podstawę dla powstawania cywilizacji (Szul 2009). Jako narzędzie komunikacji pełni on podwójną rolę: służy do przekazywania informacji ludziom posługującym się tym samym językiem, ale też do ukrywania informacji przed tymi, którzy go nie znają (Szul 2009).

Podstawową dyscypliną naukową, badającą język jako ogólny sposób komunikacji oraz poszczególne języki używane w tym celu przez człowieka, jest

${ }^{1}$ Według części badaczy również w przypadku zwierząt istnieją formy komunikacji, które można zakwalifikować jako języki (por. np. Hauser, Chomsky, Fitch 2002), jednak szczególna rola i poziom skomplikowania języków używanych przez ludzi nie ulegają wątpliwości. 
językoznawstwo, zwane też lingwistyką. Niemniej jednak w ramach wielu innych dyscyplin naukowych prowadzi się badania dotyczące języków: mogą one stanowić przedmiot badań np. archeologii, historii, literaturoznawstwa, etnologii, pedagogiki czy geografii. Celem niniejszego artykułu jest zwrócenie uwagi na możliwości badania języków z perspektywy geografii, na granice między dziedzinami jej badań i językoznawstwa oraz na terminologię wykorzystywaną do opisu badań z pogranicza obu dyscyplin.

\section{JEZYK JAKO PRZEDMIOT BADAŃ - TRUDNOŚCI ZE SPRECYZOWANIEM TERMINOLOGII}

Geografia, podobnie jak wiele innych dyscyplin badających języki, musi zmierzyć się z problemem nie zawsze precyzyjnej terminologii związanej z przedmiotem badań. Jednym ze sposobów wyróżniania poszczególnych języków jest zastosowanie kryterium zrozumiałości: różne języki są zgodnie z nim wzajemnie niezrozumiałe, podczas gdy np. użytkownicy różnych dialektów tego samego języka mogą przy ich pomocy porozumieć się między sobą (Szul 2009). Określony język - w szczególności narodowy - dzieli się następnie na język literacki oraz dialekty. Język literacki stanowi oficjalny, skodyfikowany wariant języka, wykorzystywany i promowany przez instytucje państwowe, w tym system szkolnictwa. W swoistej opozycji do niego stoją dialekty, które są odmianami języka charakterystycznymi dla pewnego terytorium, różniącymi się od języka literackiego i innych dialektów szczególnym zestawem cech fonetycznych i leksykalnych. Podobnie do dialektów definiuje się gwary, przy czym podstawową różnicą między nimi jest zasięg występowania: gwary używane są na mniejszym terytorium (np. kilku lub kilkunastu wsi) i stanowią jednostkę podrzędną w stosunku do dialektu, tak że zespół gwar o podobnych cechach wspólnie tworzy dialekt. Przy tym gwary i dialekty były pierwotnie przypisywane przede wszystkim ludności wiejskiej, co uległo zmianie m.in. wraz z intensywnymi zmianami w strukturze ludności miejskiej i wiejskiej w XX wieku².

Podział języków na ich warianty literackie oraz dialekty i gwary w praktyce stanowi jednak problem. Między użytkownikami języków, dialektów i gwar mogą, w teorii, zachodzić relacje znajdujące się pomiędzy pełną zrozumiałością a zupełnym niezrozumieniem, zaś niemal nieskończona różnorodność tych potencjalnych relacji sprawia, że kryterium zrozumiałości często nie może w sposób jednoznaczny służyć do odróżnienia języków od dialektów. W efekcie decyzja o zakwalifikowaniu danej formy do jednej lub drugiej kategorii podejmowana jest często nie przez językoznawców, lecz przez polityków. Takie rozwią-

\footnotetext{
${ }^{2}$ Ewolucję terminologii w polskim językoznawstwie dokładnie opisuje Halina Karaś, profesor polonistyki Uniwersytetu Warszawskiego, w redagowanym przez nią kompendium internetowym pt. Dialekty i gwary polskie. Online: http://www.dialektologia.uw.edu.pl/ [dostęp: 14.10.2015].
} 
zanie prowadzi czasem do paradoksalnych sytuacji, jak w przypadku północnych dialektów języka niemieckiego, które są bardziej podobne do literackiego języka holenderskiego niż niemieckiego (Szul 2009). W przypadku trudności z zakwalifikowaniem danego wariantu jako języka lub dialektu używa się niekiedy terminu „etnolekt” dla oznaczenia wariantu języka lub dialektu, którym posługuje się pewna grupa etniczna, jednak również ten termin nie jest wolny od kontrowersji (m.in. Eckert 2008) i nie stanowi w pełni satysfakcjonującego rozwiązania problemu z terminologią.

\section{BADANIA NA POGRANICZU GEOGRAFII I JĘZYKOZNAWSTWA}

Autorem pierwszych prac z pogranicza językoznawstwa i geografii był Georg Wenker, który w 1878 roku sporządził „Atlas językowy Nadrenii na północ od Mozeli oraz powiatu Siegen" (Sprach-Atlas der Rheinprovinz nördlich der Mosel sowie des Kreises Siegen, Wenker 1878), a w następnych latach pracował nad mapami językowymi kolejnych regionów Cesarstwa Niemieckiego. Mimo to za pioniera badań naukowych z tej dziedziny uchodzi szwajcarski językoznawca G. Gilliéron, który w 1881 roku opublikował „Mały atlas fonetyczny romańskiego Valais (na południe od Rodanu)" Petit atlas phonétique du Valais roman (sud du Rhône), Gilliéron 1881, a pod koniec XIX wieku we współpracy z Francuzem E. Edmontem badał zróżnicowanie dialektów we Francji i na francuskojęzycznych obszarach z nią graniczących. Efektem badań terenowych była niezwykle bogata baza danych na temat zróżnicowania dialektalnego badanego obszaru, na podstawie której na początku następnego stulecia opracowano i opublikowano ponad 1900 map językowych w ramach „Atlasu językowego Francji” (Atlas linguistique de la France, Gilliéron, Edmont 1902-1910).

Takie połączenie danych lingwistycznych z kartograficzną metodą prezentacji stanowi przykład dynamicznie rozwijającej się w XX wieku kartografii językowej. W Polsce za jej początek uznaje się rok 1934, gdy ukazał się Atlas językowy polskiego Podkarpacia (Nitsch, Małecki 1934), natomiast jej okres świetności przypada na lata po II wojnie światowej, gdy wydano m.in. Maty atlas gwar polskich (Nitsch 1957). Metodę badawczą wykorzystującą mapy językowe do zobrazowania zróżnicowania dialektów danego języka zwykło się określać mianem „geografii” lub „kartografii lingwistycznej”, a sam termin „,geografia lingwistyczna" zaczął oznaczać również, w szerszym znaczeniu, dział językoznawstwa badający zróżnicowanie geograficzne języków narodowych ${ }^{3}$. Geograficzny aspekt owych badań jest jednak bardzo ograniczony, bowiem to zjawiska językowe stanowią ich przedmiot, zaś „,geograficzność” sprowadza się przeważnie do popraw-

\footnotetext{
${ }^{3} \mathrm{http} / /$ www.dialektologia.uw.edu.pl/index.php?11=podstawy-dialektologii\&12=geografia-ling wistyczna-mwr [dostęp: 14.10.2015].
} 
nego wykorzystania metody prezentacji kartograficznej. Aspekt przestrzenny stanowi więc w tej sytuacji jedynie tło dla rozważań nad językiem.

Na możliwość prowadzenia badań nad językami z perspektywy geografii jako jeden z pierwszych zwrócił uwagę francuski geograf Albert Demangeon w artykule „Geografia języków” (La géographie des langues, 1929). Wskazał on w nim na język jako jeden z kluczowych czynników przy badaniu zmienności rozmieszczenia zbiorowisk ludzkich, podkreślając tym samym bardzo ważną rolę odgrywaną przez geografię języków w geografii człowieka. Zaznaczył przy tym, że lingwiści mają za zadanie „prowadzić” geografów w tych badaniach. O ile Demangeon przede wszystkim zwrócił uwagę na istnienie geografii językowej w ogóle, o tyle inny francuski geograf, Carlos Miguel Delgado de Carvalho, podjął próbę dokładniejszego zarysowania jej przedmiotu badań. Wskazał on na przestrzenne rozmieszczenie użytkowników języków, historyczne zmiany zasięgów występowania poszczególnych języków oraz wpływ warunków środowiska na te zmiany jako główne obiekty zainteresowania geografii językowej. Autor zaznaczył przy tym, że same zjawiska językowe leżą poza obszarem badań geografów zajmujących się językami (Delgado de Carvalho 1962).

Rozważania podjęte przez obu autorów na temat geografii języków rozwinął kolejny francuski geograf Roland Breton. Podobnie jak Demangeon podkreślał on szczególną rolę tej subdyscypliny: twierdził, że ponieważ języki definiują kulturę, a zarazem rozmieszczenie języków mówi o obecnych i przeszłych procesach zachodzących w społeczeństwie, geografia języków powinna zajmować centralne miejsce w geografii kultury. Równocześnie Breton dokonał wyraźnego rozróżnienia pomiędzy zadaniami lingwistyki i geografii. Ta pierwsza, reprezentowana przez geografię lingwistyczną (géographie linguistique), ma zajmować się badaniem języków, identyfikacją ich zróżnicowanych form (gwar, dialektów), analizą ich rozmieszczenia i sporządzaniem map językowych. Ta druga natomiast, reprezentowana przez geografię języków (géographie des langues), ma za zadanie badać „, zewnątrz” języki już zdefiniowane przez lingwistów, analizować ich rozmieszczenie $\mathrm{w}$ przestrzeni i zmienność tego rozmieszczenia w czasie, przy czym przedmiotem badań nie są tu same języki, lecz społeczności, które się nimi posługują. Autor podsumował swoje rozważania stwierdzeniem: ,praca językoznawcy kończy się tam, gdzie zaczyna się praca geografa" (Breton 1975).

Wyraźny podział na geografię językową i lingwistyczną sformułowany przez Bretona nie jest jedyny i uniwersalnie obowiązujący. Ciekawym przykładem znacząco odmiennego spojrzenia na badanie języków w geografii jest definicja hasła „język" (language) figurująca w Dictionary of Human Geography opublikowanym przez wydawnictwo Wiley-Blackwell. Autor artykułu dokonuje w nim podziału geograficznych badań nad językami (a także innymi wariantami, takimi jak dialekty czy idiolekty) na dwie główne kategorie: „geografię języka i w języku” (geography of and in language) oraz ,język geografii i w geografii” (language 
of and in geography). Druga kategoria dotyczy języka używanego przez geografów jako wyrazu ich tożsamości, odzwierciedlającego zarazem sytuację społeczną i polityczną, w której ci geografowie funkcjonują - stanowi on zatem wyraz subiektywnej wizji świata, który można badać na przykład przez pryzmat teorii postkolonialnej. Bardziej skomplikowana, a zarazem kontrowersyjna jest pierwsza kategoria, w której wyróżnione są trzy przedmioty badań. Pierwszy to rozmieszczenie języków, a zajmującą się nim subdyscyplinę autor określa mianem language geography (geografia językowa) lub language mapping (kartowanie języków). Drugi przedmiot badań stanowi przestrzenne i społeczne zróżnicowanie form językowych, nazwane linguistic geography (geografią lingwistyczną) lub dialect geography (geografią dialektów). Trzecia grupa zawiera pochodzenie i zmiany nazw geograficznych, czyli toponimów (Withers 2009). Taka klasyfikacja zupełnie zaciera granice między geografią a lingwistyką, znajdują się w niej bowiem zarówno elementy bardziej związane z geografią (pierwsza grupa), jak $\mathrm{i}$ te bliższe językoznawstwu (druga grupa), chociaż z perspektywy autora wszystkie one stanowią element geografii.

W pewnym sensie przeciwieństwem powyższej klasyfikacji jest definicja użyta m.in. przez językoznawcę Halinę Karaś. Autorka traktuje geografię językową i lingwistyczną jako synonimy, wskazując przy tym na cztery możliwe znaczenia tejże w językoznawstwie. Po pierwsze może ona oznaczać konkretną metodę badawczą, polegającą na sporządzaniu map językowych - w tym znaczeniu jest ona synonimem kartografii lingwistycznej; po drugie może być rozumiana jako dział językoznawstwa zajmujący się badaniem zróżnicowania przestrzennego danego języka narodowego; po trzecie geografia lingwistyczna/językowa może oznaczać terytorialne rozmieszczenie zjawisk językowych; po czwarte, w najszerszym znaczeniu, jest to dziedzina badań, która obejmuje wszystko to, co ma charakter jednocześnie językowy i geograficzny - w tym znaczeniu jej synonimem jest geolingwistyka ${ }^{4}$. Porównując tę klasyfikację z poprzednimi, daje się zauważyć, że dwie ostatnie kategorie mogą dotyczyć także przedmiotu badań geografii. Zarazem użycie terminu „geografia językowa”, jako synonimu geografii lingwistycznej, wprowadza dodatkowe zamieszanie przy konieczności zestawienia jej z geografią języków jako zupełnie inną dziedziną.

\section{PROPOZYCJA USYSTEMATYZOWANIA TERMINOLOGII}

Na podstawie dotychczasowych rozważań można stwierdzić, że chociaż istnieje możliwość dość wyraźnego nakreślenia granicy między lingwistyką a geografią, to jednak niekiedy brakuje spójności w wykorzystywaniu terminów okre-

\footnotetext{
${ }^{4} \mathrm{http} / / /$ www.dialektologia.uw.edu.pl/index.php?11=podstawy-dialektologii\&12=geografia-ling wistyczna-mwr [dostęp: 14.10.2015].
} 
ślających odpowiednie subdyscypliny. Promowanie rozróżnienia na „geografię lingwistyczną”, stanowiącą część językoznawstwa, oraz „geografię języków”, będącą dziedziną geografii, wydaje się słusznym rozwiązaniem. Warto w tym miejscu zwrócić uwagę na potencjalne wątpliwości związane z polskim odpowiednikiem angielskiego terminu geography of languages i francuskiego géographie des langues - czy odpowiedniejsza jest forma „geografia języków” czy ,językowa”? Angielski przyimek of i francuski de odpowiadają polskiemu użyciu dopełniacza, co wskazywałoby na formę ,geografia języków”. Przy tym termin ,geografia językowa" - którego angielskim odpowiednikiem byłoby określenie language geography - jest mniej jednoznaczny i pojawia się zarówno jako subdyscyplina geografii, jak i lingwistyki, a niekiedy jako połączenie obu. Podobne wątpliwości budzi zresztą stosunkowo nowe pojęcie ,geolingwistyka”, które ze względu na formę (,lingwistyka” w nazwie) oraz dotychczasowe użycie wydaje się bliższe lingwistyki, a w szczególności geografii lingwistycznej, jednak jednocześnie bliższe geografii niż ta ostatnia ${ }^{5}$.

Reasumując, proponowane jest wykorzystywanie terminu „geografia lingwistyczna" dla określenia działu językoznawstwa zajmującego się badaniem samych języków (zjawisk językowych) i ich zróżnicowania w przestrzeni prezentowanej przez „kartografię lingwistyczną” w postaci map językowych, zaś używanie terminu „geografia językowa” zarezerwowane jest dla określenia działu geografii, który bada przestrzenny aspekt rozmieszczenia języków, skupiając się na ruchach ludności, powodujących zmiany tego rozmieszczenia, a także na społecznych, politycznych i gospodarczych przyczynach tych zmian. Stosunkowo najbardziej kontrowersyjny termin ,geolingwistyka” mógłby w tej sytuacji służyć do określania dziedziny badań łączących elementy geografii i językoznawstwa.

\section{PODSUMOWANIE - PERSPEKTYWY BADAŃ NA POGRANICZU GEOGRAFII I LINGWISTYKI}

Mówiąc o możliwościach prowadzenia badań znajdujących się na pograniczu geografii i językoznawstwa, warto na koniec zastanowić się, czy badania prowadzone w ramach obu dyscyplin są rozłączne, czy też istnieją między nimi punkty wspólne. Na podstawie analizy przeprowadzonej w niniejszym artykule wydaje się, że takowe punkty wspólne istnieją - językoznawca zajmujący się geografią lingwistyczną poza znajomością geografii badanego obszaru powinien również posiadać wiedzę kartograficzną, zaś geografowi zainteresowanemu geo-

\footnotetext{
${ }^{5}$ Wątpliwości dotyczące znaczenia terminu w ciekawy sposób przedstawione są w tekście proponującym udział w warsztatach dotyczących geolingwistyki organizowanych w College of Liberal and Fine Arts w University of Texas at San Antonio (http://colfa.utsa.edu/nwav39/workshops/ geolx.pdf [dostęp: 14.10.2015]). Jako element odróżniający geolingwistykę od np. geografii lingwistycznej wskazuje się łączenie lingwistyki nie tylko z mapami, ale również z geografią kulturową.
} 
grafią języków wiedza językoznawcza może pomóc w lepszym rozumieniu procesów dotyczących rozmieszczenia ludności posługującej się danym językiem lub dialektem. W praktyce oznacza to, że chociaż badania czysto geograficzne lub czysto językoznawcze w ramach - odpowiednio - geografii języków i geografii lingwistycznej są zapewne możliwe, to jednak badania interdyscyplinarne mogą w tym przypadku przynieść znacznie więcej korzyści. Wydaje się więc, że współcześnie, wbrew postulatowi Rolanda Bretona, praca językoznawcy niekoniecznie musi kończyć się tam, gdzie zaczyna się praca geografa, lecz obaj mogą współpracować na pograniczu swoich dyscyplin.

\section{SUMMARY}

The language as a socially shaped tool that serves communication between human beings is one of the main distinguishing features of our species, while at the same time being a basic medium for transmitting culture. While the main scientific discipline that studies languages is linguistics, there are other fields of knowledge that have their share in extending the knowledge about them. The purpose of this paper is to draw attention to the possibilities of studying languages from the perspective of geography, to find the limit between the areas of research of geography and linguistics, as well as to systematize the names of subdisciplines that study this "borderland area". In the introduction, the functions of language and the problems with making clear distinctions between languages and dialects are outlined. In the following part of the article, the author tries to systemize the terminology related to research in the area of study between geography and linguistics by analyzing similarities and differences between such Polish terms as geografia języków (geography of languages), goegrafia lingwistyczna (linguistic geography) and geolingwistyka (geolinguistics), as well as their equivalents in English and French. This serves as the basis to determine in which fields geography and linguistics can complement each other, and where lies the limit between those disciplines. The final part of the paper consists of an attempt to outline the future prospects of geographical research on languages and answer the question whether geography should cooperate with linguistics in such research and if so, to what extent.

\section{LITERATURA}

Breton R. J. L., 1975: La place de la géographie des langues, Annales de géographie, 84 (465), 513-525, doi: 10.3406/geo.1975.19820.

Delgado de Carvalho C. M., 1962: The geography of languages, P. L. Wagner, M. W. Mikesell, Readings in cultural geography, 75-93.

Demangeon A., 1929: La géographie des langues, Annales de géographie, 38 (215), 427-438, doi: 10.3406/geo.1929.9889.

Eckert P., 2008: Where do ethnolects stop?, International Journal of Bilingualism, 12: 25-42, doi: 10.1177/13670069080120010301.

Gilliéron J., 1881: Petit atlas phonétique du Valais roman (sud du Rhône), Honoré Champion, Paryż.

Gilliéron J., Edmont E., 1902-1910: L'atlas linguistique de la France, 9 tomów, Honoré Champion, Paryż.

Hauser M. D., Chomsky N., Fitch W. T., 2002: The Faculty of Language: What Is It, Who Has It, and How Did It Evolve?, Science 298: 1569-1579, doi: 10.1126/science.298.5598.1569. 
Nitsch K., Małecki M., 1934: Atlas językowy polskiego Podkarpacia, Polska Akademia Umiejętności, Kraków.

Nitsch K., 1957: Mały atlas gwar polskich, Zakład Narodowy im. Ossolińskich, Wydawnictwo PAN, Wrocław, Kraków.

Szul R., 2009: Język, naród, państwo. Język jako zjawisko polityczne, Wydawnictwo Naukowe PWN, Warszawa, 7, 8-9.

Warf B., 2006: Language, Geography of, [w:] B. Warf (red.), Encyclopedia of Human Geography, 270-275, Sage Publications, Thousand Oaks, 270.

Wenker G., 1878: Sprach-Atlas der Rheinprovinz nördlich der Mosel sowie des Kreises Siegen, Marburg, [nieopublikowany].

Withers C. W. J., 2009: „Language”, [w:] G. Derek, R. Johnston, G. Pratt, M. Watts, S. Whatmore (red.), The Dictionary of Human Geography, 411-412, Wiley-Blackwell, Oxford. 